\title{
Actual Issues of Forensic Activities in Ukraine and the Possibility of Implementing International Standards of the Industry in the Ukrainian Legislation
}

\author{
Kotlyarenko Lidiya \\ Doctor of Biological Sciences, Professor, \\ Professor of Department of theory, methodology and organisation of physical \\ training and sports of the National University of Defence of Ukraine \\ ORCID: 0000-0001-5237-8564 lida_oleg@ukr.net \\ Pavlovska Nataliia \\ PhD of Juridical Sciences, Associate Professor, Associate Professor of Theory and \\ History of Law, Kyiv National Economic University, Kiev, Ukraine \\ ORCID ID 0000-0003-3311-0364 wwwpav@gmail.com
}

\section{Svoboda Eugenia}

PhD of Juridical Sciences, Associate Professor, Professor of Department of Forensic Support and Forensic Expertise of the National Academy of Internal Affairs, Kiev, Ukraine

ORCID ID 0000-0002-8639-8333 jeechka@ukr.net

Symchuk Anatolii

Senior Teacher at the Department of Criminal Procedure of the National Academy

Internal Affairs, Kyiv, Ukraine

ORCID ID 0000000286638210 symchukas@gmail.com

\author{
Kharchenko Serhii \\ Senior Teacher at the Department of Criminal Procedure of the National Academy \\ Internal Affairs, Kyiv, Ukraine \\ ORCID ID 0000-0001-5603-8030 F500@i.ua
}

\begin{abstract}
International standards exist in any field of legal regulation however, they are mostly identified with standards that regulate the technical sphere, since they are the most common ones. Nonetheless, today it is hard to imagine any area of public life with no generally recognized international standards. European legal standards are formed within the framework of the two most regional international associations - the Council of Europe and the European Union. The Council of Europe sets, first of all, standards in the humanitarian sphere: human rights, environment protection, and constitutional law, which is determined by the goals and purpose of its functioning. The European Union (hereinafter referred to as the EU) using directives, regulations, and other legal acts sets standards for most areas of the EU population's life. It should be noted it is during the development of 'standardization' in the European law that specific development of public relations in the EU takes place. Defining the EU legal standard as a separate category of norms of the European law, it is noteworthy that this term is used in a broad sense as a 'legal standard' and incorporates such elements as the general principles of the EU law and the 'common values' of the EU - they relate to people, environment, economic issues, and so on. The European Convention for the Protection of Human Rights and Fundamental Freedoms 1950 is a classic example of their implementation. In a narrow sense, this term has a specific meaning and does not coincide with the concept of 'legal standard', e.g. these are standards in the technical field that are adopted by the European Committee for
\end{abstract}


Standardization, that is, in its content, it is a technical publication that is used as a norm, rule, guide or definition. Therefore, they relate to products, services, or systems and are the basis for convergence and interaction within the growing market of various business sectors. Today, in international law de facto there is a system of standards that regulate various aspects of international relations [2].

Keywords: European Union, expert, implementation, international standards, examination, procedures.

Introduction Modern globalization and integration of international norms into the national legislation offers new challenges and priorities for the transposition of international standards into forensic activities of Ukraine. The study of foreign practice of regulating forensic activities provides new opportunities to improve the quality and professional competence of forensic examinations conducted by respective institutions. Successful accession to the European community is dependent on internal democratic development, achieving new quality of society, and irreversible democratic transformations in all spheres of social life [1].

Therefore, the implementation of international standards into Ukrainian legislation renders it possible to reach a different level of development of public relations, in particular in such area as forensic activities should be effectively conducted, and administrative and legal regulation of forensic activities should take place without violating human rights and freedoms [3].

Research on the EU legislation regulating forensic activity shows that the norms and procedures of procedural legislation are aimed at establishing the institution of modern adversarial criminal proceedings. In most EU countries, the professional training of an expert and the availability of the requisite knowledge and experience are crucial in assessing their qualifications. The issue of acquiring the status of a forensic scientist by a certain person is within the competence of the court. The 'departmental subordination' of forensic scientists is not crucial when selecting them for conducting a forensic examination. Uniform standards of legal regulation of forensic science are laid down by the European Court of Human Rights, whose jurisdiction extends to all Member States of the Council of Europe (Ukraine joined the organization in 1995) that have ratified the European Convention for the Protection of Human Rights and Fundamental Freedoms. According to Article 42 of the Rules of the European Court of Human Rights, the court may hear any person as an expert or invite independent experts. In the Netherlands, forensic experts from state forensic institutions conduct examinations and research upon police complaints, not the courts. The court invites experts regardless of their primary place of employment. In the UK, an expert is usually invited by one of the parties to the process to conduct examinations or research and is considered, respectively, as an expert from either prosecution or defense. The list of experts is maintained, in particular, by the Law Society of United Kingdom. In the Czech Republic, forensic science is regulated by Law No. 36 of April 20, 
1967 'On Experts and Translators'. Lists of experts (additions and amendments thereto) are kept by each regional court and sent to the Ministry of Justice, the regional prosecutor's office, Czech Police (regional offices), district and military courts, and district prosecutor's offices. The centralized list of experts maintained by the Ministry of Justice comprises lists of regional courts, which are distributed by specialty (branch of knowledge), as well as regional lists. The state authority of the Czech Republic may also appoint a person who is not included in the list as an expert. In addition to the centralized list of experts, the Czech Ministry of Justice maintains a list of organizations authorized to give their expert opinions. Such organizations are not only governmental and non-governmental institutions that carry out expert activities on a professional basis but also higher educational institutions, scientific institutes, and organizations that - upon the request of public authorities - may carry out expert research and draw up a forensic report. An expert in Finland and Sweden is a person who conducts a forensic examination, has special knowledge and skills for this purpose, and a corresponding higher education. The systems of expert institutions in Finland and Sweden consist of public and private laboratories that carry out forensic expertise; educational institutions that teach specialists in the field of forensic science. A special feature of expert training in Finland and Sweden is that after completing their studies in a higher educational institution, the expert receives a Master's Degree and certificate, on the basis of which they are entitled to conduct forensic examination in public authorities and in private practice. The procedural legislation of Finland and Sweden grants a forensic expert the status of a witness and does not contain the term 'specialist'. The expert and specialist positions in government laboratories of Finland are allocated by scientific degree: an expert has a Master's degree, and a specialist has a Bachelor's degree as confirmed by the corresponding higher education diplomas. In Belgium and France, an expert is considered to be any person who has the appropriate education, experience, and in-depth knowledge in one or more fields of knowledge. Experts in France and Belgium join professional one - or multidisciplinary associations, unions, and chambers (the French National Chamber of Experts, the Belgian Association of Experts which include experts in various fields of knowledge as members). The Institute of private expertise has been successfully operating in German legal proceedings for a long time. If the parties to the proceedings agree to use certain persons as experts, the court must give its consent (section 403 of the Civil Procedural Code of the Federal Republic of Germany). In some European countries, according to ISO/IEC17024 General requirements for bodies operating certification of persons, certification of forensic experts has been initiated. According to paragraph 4.2.1 of ISO/IEC 17024, certification bodies cannot be subordinated to institutions and bodies employing forensic experts. 
Despite the fact that today in Ukraine personnel in various fields of human activity is also certified by special bodies established in accordance with DSTU ISO/IEC 17024:2005 'General requirements for bodies operating certification of personnel', expert and qualification commissions of the dedicated governmental institutions should have the exclusive right (monopoly) to provide internship (training), certify forensic expert and issue a forensic examination permit which have not licenses for providing educational services and only three percent of their staff have scientific degrees. In higher educational institutions of Ukraine whose activity of teaching Masters in 'Forensic Science' is licensed, 95\% of instructors and lecturers have scientific degrees and academic ranks. However, such higher education institutions aren't authorized to certify forensic experts and issue them certificates for conducting forensic examinations (contrary to governmental specialized expert institutions that have licenses to provide educational services). The new Criminal Procedure Code of Ukraine provides for the possibility of involving an expert by both the prosecution and the defense. However, as law enforcement practice shows, it is impossible to exercise the right of the defense party to engage an independent expert for forensic examinations of physical evidence. To solve this problem, it is necessary to develop a set of norms, to provide an opportunity for all participants of the criminal process to initiate alternative forensic examinations, norms that will allow legalizing in criminal proceedings the results of extrajudicial examinations conducted by private experts on a contractual basis by order of the parties. The analysis of the EU legislation shows that the principles of ensuring the independence of an expert are consistently implemented worldwide; focusing on the availability of special knowledge required for solving the problems of justice, rather than on departmental affiliation; ensuring the principle of competition of experts involved by various parties to the process; and other principles that are crucial for ensuring a truly independent, objective and qualified examination of legal proceedings. At the same time, the existence of the Institute of private expertise in the EU countries is not only one of the guarantees of ensuring the legal rights and freedoms of citizens and the interests of the society, but also allows to significantly reduce the budget costs for the maintenance of state specialized expert institutions. One of the important elements of successful integration of Ukraine into the EU is achieving a certain level of consistency of Ukrainian legislation with the EU legal norms on the use of special knowledge in a lawsuit [4].

Forensic science, as well as forensic activity, has recently undergone significant changes. Looking through the prism of new international standards and innovative technologies for their application, the changes made to the legislation of Ukraine regarding forensic examinations, do require a comprehensive approach for their revision. In addition to establishing a state monopoly on 
the conduct of examinations, experts blame the Ministry of Justice on the incomprehensible procedure for professional development and the monopoly on the certification of experts. The regulation on expert qualification commissions and certification of judicial experts, approved by the Order of the Ministry of Justice of Ukraine dated 03.03.2015 No. 301/5, contains unacceptable requirements for the professional training of judicial experts who are not employees of the dedicated governmental institutions resulting in obstacles to their professional activities. One of the legal problems related to the classification of forensic examinations is the provision of Article 7 of the Law of Ukraine 'On Forensic Examination' concerning forensic examinations to be conducted exclusively by dedicated governmental institutions. At the same time, the concept and list of forensic examinations is contained only in departmental normative acts, namely in orders of the Ministry of Justice of Ukraine No. 53/53 of 08.10.1998 and the Security Service of Ukraine No. 8554 of 24.12.2014 If we consider the relevant orders of the Ministry of Justice of Ukraine and the Ministry of Internal Affairs of Ukraine, then given almost identical types of expert specialties, the class of forensic examinations is not discerned in these orders. The imperfection of Article 7 of the Law of Ukraine 'On Forensic Expertise' and inconsistency of statutory instruments of the ministries that provide expertise, must be resolved in one of the following ways: 1. Leave the provision in the Article of the Law with a clear list of examinations to be performed exclusively by dedicated governmental institutions. In this case, the term "forensic" should be deleted. 2. Delete the said provision and allow all examinations, except for forensic medical and forensic psychiatric ones, to be conducted by non-governmental expert institutions and private experts. With the development of the competitive system of judicial proceedings, the ban on the performance of these examinations to a certain extent restricts the rights of the defense team to select forensic experts. The provision of Article 10 of the Law regarding the concept of 'forensic expert' is controversial. On the one hand, part one states that 'forensic experts can be persons having the requisite knowledge to provide an opinion on the issues under investigation', on the other - part three contains limitations for conducting examinations by the level of education and relevant training. Given the uncertainty of legislation, judicial practice allows for consideration in courts of opinions provided in the form of acts or certificates of specialists who do not have the qualifications of a forensic expert. For example, such independent organizations as the Independent Institute of Forensic Examinations or the Forensic Independent Examination of Ukraine offer services for conducting trace, handwriting, technical examination of documents that are traditional forensic examinations and according to the current legislation can not be performed by them. Such findings, if not conducive to the final adjudication, in many cases serve as a basis for the court to decide on the appointment of a 
re-examination. On the one hand, it is quite acceptable that in an adversarial system of legal proceedings, the parties can produce any documents in support of their position, and the court should consider them impartially, taking into account that no evidence has a predetermined force. On the other hand, there are questions about the quality of such conclusions and the qualifications of specialists as compared to experts from dedicated governmental institutions. When considering the Law of Ukraine 'On Forensic Examination', we should also pay attention to certain provisions that have been again and again considered by scientists and require improvement. Starting with the enacting clause, which reads that 'this law defines the legal, organizational and financial basis for forensic examinations...', although the title refers to 'forensic expertise'. It is clear that the difference in the concepts of 'forensic examination' and 'forensic expert activity' is quite significant, so the law should have the title 'On Forensic Activity'.

The general provisions of the law must explain the content of the main terms that form the basis of forensic activity. The law must explain such terms as 'requisite knowledge', ' forensic activity' and give definition of the 'subject of forensic examination'. The types and procedures for conducting various types of examinations - primary, re-examination, supplementary expert, comprehensive expert examination, single-discipline review - are also subject to definition and detailed description $[5]$.

Conclusion The situation in forensic science in Ukraine, in particular in matters related to the implementation of forensic activity in court proceedings, requires further elaboration and clarification, taking into account the reform of the judicial system and the development of new trends and new technologies for conducting examinations.

\section{References}

1. G. Filonenko. Democratization of Ukrainian society as a fundamental component of Ukraine's entry into the European space. Veche. 2011. \# 2 (Jan.). P. 12.

2. M. Khaustova. International standards in the context of European integration processes in Ukraine. Journal of National Academy of Legal Sciences of Ukraine \#2 (89) Pp. 44-45.

3. O. Oleinik. Foreign experience of administrative and legal regulation of forensic activities. Customs Business. 2013. No. 4 (88) P. 270.

4. G. K. Avdeeva. Problems of harmonization of Ukrainian legislation in the field of forensic expertise with the legislation of the European Union - access mode http://dspace.nlu.edu.ua/bitstream/123456789/7223/1/Avdeeva_634.pdf

5. I. Pyrig. Classification of forensic examinations and problems of improving legislation, Kharkiv 'Pravo' 2018, p.25, access mode:

https://www.hniise.gov.ua/user_files/File/sbornik/2018/\%d0\%9a\%d0\%be\%d0\%bd\%d1\%84_\%d0\% 90\%d0\%ba\%d1\%82\%20\%d0\%bf\%d0\%b8\%d1\%82\%d0\%b0\%d0\%bd\%d0\%bd\%d1\%8f\%20\%d1\% 81\%d1\%83\%d0\%b4\%20\%d0\%b5_2018.pdf 